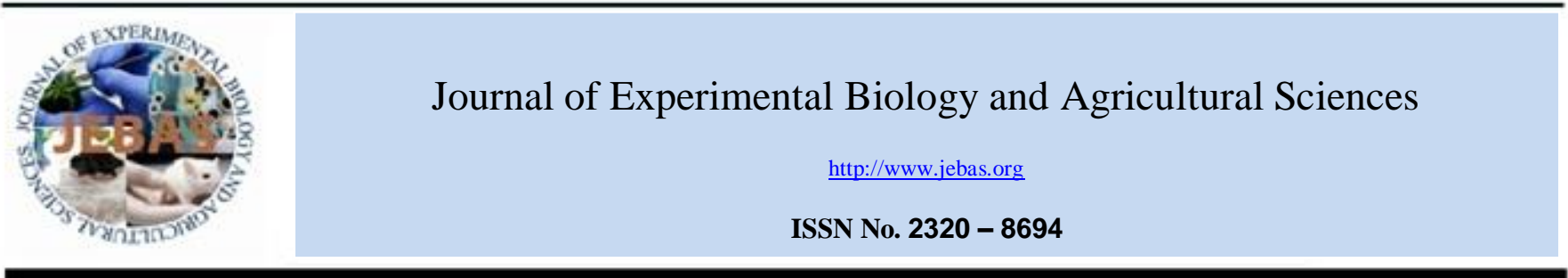

\title{
PERFORMANCE OF RICE HYBRIDS IN EASTERN GANGETIC ALLUVIAL ZONE OF WEST BENGAL, INDIA
}

\author{
Somnath $\operatorname{Sardar}^{1}{ }^{*}$, Kajal Sengupta $^{1}$, Sukamal Sarkar ${ }^{1}$, D.C. Roy ${ }^{2}$, B.C.Patra ${ }^{1}$ \\ ${ }^{1}$ Department of Agronomy, BCKV, Mohanpur, Nadia, 741252 \\ ${ }^{2}$ Department of LFC, WBUAFS,Mohanpur, Nadia, 741252
}

Received - October 11, 2018; Revision - November 30, 2018; Accepted - December 12, 2018

Available Online - December 15, 2018

DOI: http://dx.doi.org/10.18006/2018.6(6).959.965

\section{KEYWORDS \\ Rice hybrids \\ HYV \\ Germination \\ Grain yield \\ Harvest index}

\begin{abstract}
A field experiment was conducted at university farm of Bidhan Chandra Krishi Viswavidyalaya, West Bengal, India on summer rice during 2015-2016 and 2016-2017 to observe the performance of hybrid varieties under New Alluvial Zone of West Bengal. The experiment was laid out in Randomized Block Design with three replications. Square method of transplanting $(20 \mathrm{~cm} \times 20 \mathrm{~cm})$ was maintained for all varieties (27P22, 27P37, 27P36, 28P67, 27P31, 29P01, ArizeTej Gold, and Arize 6129) and $\mathrm{N}-\mathrm{P}_{2} \mathrm{O}_{5^{-}}$ $\mathrm{K}_{2} \mathrm{O}$ was applied @ 140:60:60 kg/ha for hybrids. The results of study revealed that the hybrid varieties exhibited superiority in respect of different growth parameters like plant height, LAI, aerial dry matter accumulation, number of tillers per hill etc over the control variety HYV Satabdi (IET 4786). Among various tested rice hybrids, maximum grain yield (7.13t/ha) and harvest index (49.65\%) were recorded in 28P67. The results of study revealed that both grain and straw yield of hybrid varieties were significantly higher than the HYV Satabdi (control variety) which might be due to better growth parameters and yield components of hybrids.
\end{abstract}

* Corresponding author

E-mail: somnathsardar92@gmail.com_Somnath Sardar2

Peer review under responsibility of Journal of Experimental Biology and Agricultural Sciences.

Production and Hosting by Horizon Publisher India [HPI] (http://www.horizonpublisherindia.in/).

All rights reserved.
All the article published by Journal of Experimental Biology and Agricultural Sciences is licensed under a Creative Commons Attribution-NonCommercial 4.0 International License Based on a work at www.jebas.org.

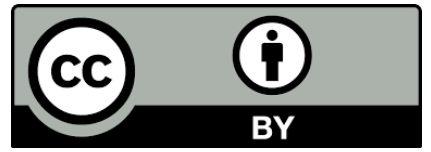




\section{Introduction}

Rice (Oryza sativa L.) is one of the most important cereal crops of India and is used as a staple food for more than $60 \%$ of the total population of the country (DAC, 2010). It is rich in starch and provides more energy that's why it is called high calorie food. It accounts for about $43 \%$ of total food grain production and $55 \%$ of total cereal production in India (Singh et al., 2012). India has the world's largest acreage under rice at 43.97 million hectare and second largest producer, 104 million tonnes next only to China (Anonymous, 2018). In India, total area under rice cultivation is decreasing at rapid rate; on the other hand the demand for rice is increasing with the growing population. India's population is projected to be 1.378 billion by 2030 and in order to meet the domestic demand of increasing population the present day production of about 100 million tons of rice has to be increased to 130 million tons by the year 2030 (Viraktamath, 2011). Therefore, to fulfil the gap between demand and supply, it is required to increase the productivity of rice i.e. production per unit area in many folds. On the other hand there is a yield plateauing in high yielding rice in our country like other south-east Asian countries. Introduction of hybrid varieties with high potentiality in yield is the best alternative for increasing the rice production without increasing its cultivated area. Hybrid rice technology has also been proved to be one of the most feasible and readily adoptable approaches to meet the domestic demand. The rice hybrids, recently introduced in cultivation, on an average, give $20-30 \%$ higher yield over the common high yielding varieties (Prasad, 2012). The present study was conducted to evaluate the performance of rice hybrids as compare to popular high yielding variety of rice during monsoon or kharif season in new alluvial zone of West Bengal, India.

\section{Materials and Methods}

Field experiment was conducted to evaluate the performance of different rice hybrids during winter season of 2015-2016 and
2016- 2017 at the University Research Farm $\left(22^{\circ} 56^{\prime} \mathrm{N}\right.$ latitude and $88^{\circ} 32^{\prime}$ E longitude, $9.5 \mathrm{~m}$ above MSL), Bidhan Chandra Krishi Viswavidyalaya, Nadia, West Bengal, India. The experiment was conducted in clay-loam soil having good irrigation and drainage facilities. The experiment was laid out in randomized block design with three replications and eight hybrid rice varieties viz., 27P22, 27P37, 27P36, 28P67, 27P31, 29P01, ArizeTej Gold, and Arize 6129 while one high yielding variety (HYV) Satabdi (IET- 4786) used as standard check. A common spacing $(20 \mathrm{~cm} \times 20 \mathrm{~cm})$ was maintained for all varieties, and a uniform recommended doses of $\mathrm{N}-\mathrm{P}_{2} \mathrm{O}_{5}-\mathrm{K}_{2} \mathrm{O}: 140: 60: 60 \mathrm{~kg} \mathrm{ha}^{-1}$ was applied for hybrids and 120:60:60 kg ha ${ }^{-1}$ for HYV. Nitrogen fertilizer (urea) was applied in three equal splits at an interval of 25 days, however, total amount of phosphate (Single Super Phosphate) was applied as basal and potash fertilizer (MOP) was applied in two equal splits at final puddling and at 25 days after transplanting (DAT). The different growth parameter like plant height, tiller number, leaf area index (LAI), total dry matter accumulation (DMA) were recorded.

Yield component like panicle $\mathrm{m}^{-2}$, filled grains panicle ${ }^{-1}$, test weight of seeds were recorded and calculated. The grain yield and straw yield were recorded. Harvest index (HI) for each variety was calculated from data on straw and grain yield. Statistical analysis for SEm and CD was done by using methodologies as laid down in Gomez \& Gomez (1984).

\section{Results and Discussion}

\subsection{Growth attributes}

Data presented in figure1 represented the required time for germination after the sowing of different rice hybrids as well as high yielding variety (HYV) of rice and it was observed that the time required for germination ranges from 5 to 6 days and that was found statistically not significant. Among the tested varieties, Arize 6129, 27P31 and 29P01 took 6 days while varieties

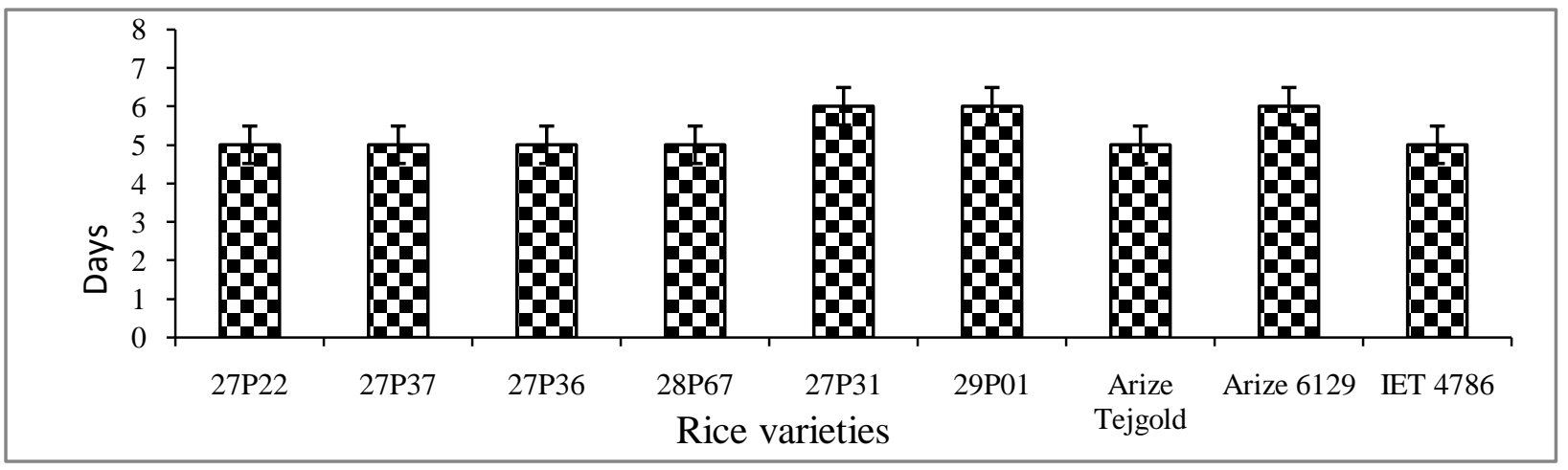

Figure 1 Days required for germination of different rice varieties

Journal of Experimental Biology and Agricultural Sciences http://www.jebas.org 
IET4786, Arize Tejgold, 27P22, 27P37, 27P36, 28P67 took only 5 days to germinate the seeds.

Regarding the time taken for panicle emergence and 50\% flowering by the different rice varieties, it was recorded 53 to 60 days and 60 to 67 days respectively and significant difference had been found between the hybrids and HYV (control) for both the cases. Among the hybrids, 27P36 took significantly higher time (60 days) in panicle emergence after transplanting which was statistically at par with 27P37 (59 days), 28P67 (58 days) and 27P31 (58 days) whereas the lower data noted in rice hybrid Arize 6129. Similar trend had also been recorded in case of time for $50 \%$ flowering among the rice hybrids. However, HYV of rice,
IET-4786 (Control) took significantly lowest time for panicle emergence (53 days) as well as that of $50 \%$ flowering (60 days) (Figure 2) \& (Table 3).

From the recoded data, it was observed that total duration of rice varieties varied from 120 days to 130 days. Among the tested hybrid verities, hybrid 29P01 took maximum time i.e. 130 days to mature which was significantly higher than the control followed by hybrids 27P22, 27P36 and 27P31 took 129 days which were statistically at par with 29P01. However, IET-4786 (Control) took significantly lowest time i.e. 120 days to get matured compare with other remaining varieties (Figure 3) \& (Table 3).

Plant height of rice was progressively increased from

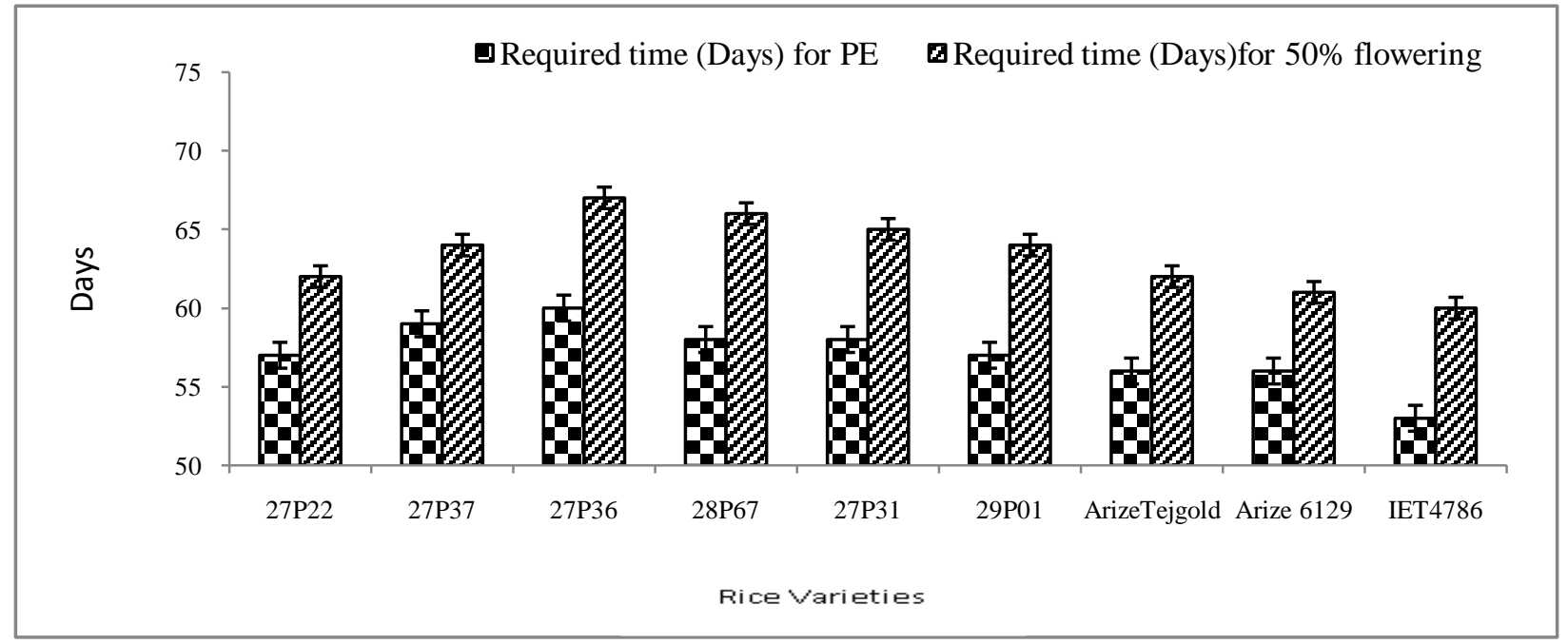

Figure 2 Days required for Panicle Emergence (PE) and 50\% flowering of rice varieties

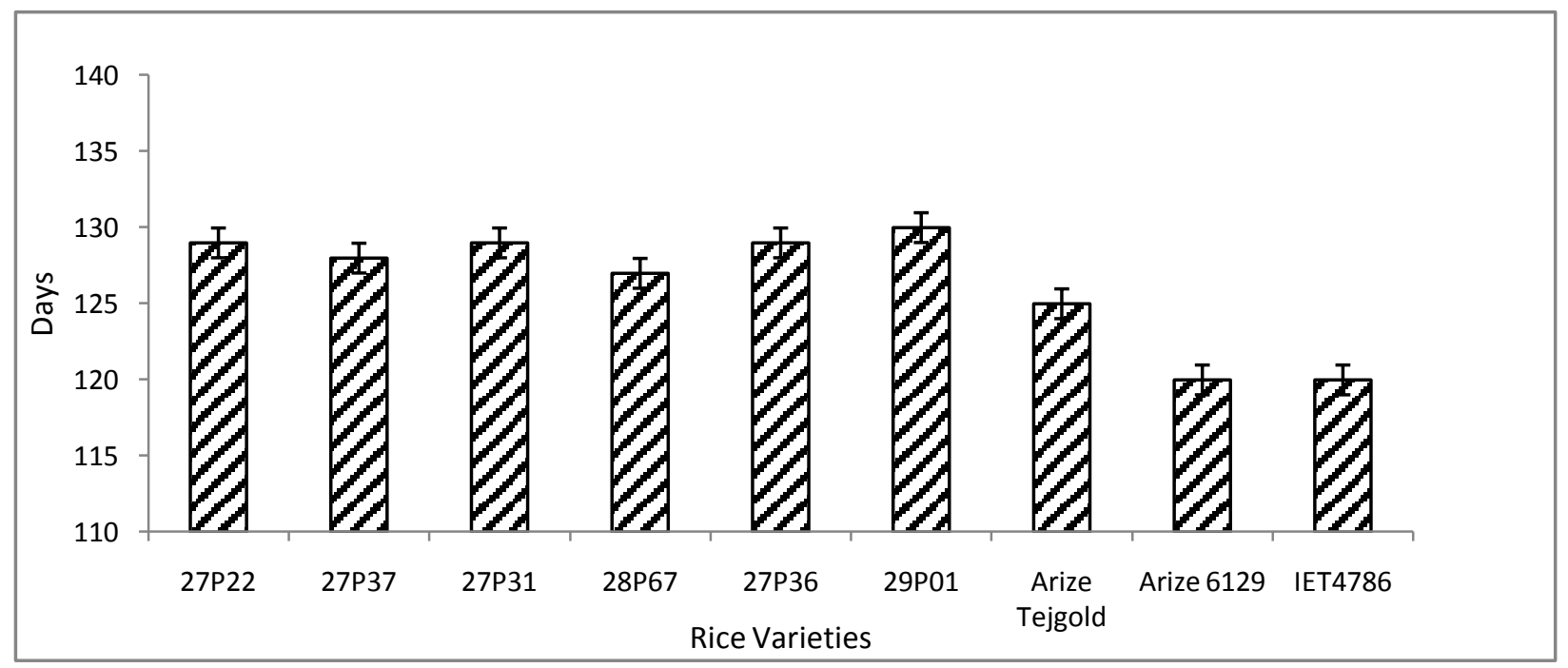

Figure 3 Total duration in days of the different rice varieties

Journal of Experimental Biology and Agricultural Sciences http://www.jebas.org 
transplanting to maturity including slow increase at early and late phase of life cycle. Sarkar et al. (2016) also reported that plant height increased progressively with the advancement of time and growth stages from early growth to maturity. It was also recorded that plant height of different rice variety was statistically at par (CD at 5\% level) with each other at early growth stages (30 DAT and 60 DAT). However, at maturity stage (90 DAT) the hybrid variety 29P01 recorded maximum plant height $(102.5 \mathrm{~cm})$ which was significantly higher than the control variety HYV IET 4786 (Table 1). Bhuiyan et al. (2014) reported the similar significant effects on plant height at maturity for different rice hybrid over high yielding varieties.

From the investigation, it was found that among the nine varieties, hybrid 28P67 recorded highest number of tillers.
HYV Satabdi produced the lowest number of tillers $\mathrm{m}^{-2}$ (Table 1). Hybrid rice generally had higher tillering ability than conventional varieties, similarly, Akram et al. (2007) also reported that two hybrids viz., MK Hybrid 111 and 27P72 produced more productive tillers than HYV KS 282. The hybrid rice variety, Tia showed superiority in respect of growth parameters like tillers hill ${ }^{1}$ (Sarkar et al. 2016).

Data presented in figure 4, revealed that leaf area index (LAI) value was highest in hybrid 28P67 and it was lowest in Arize Tejgold. Same types of results were also recorded by Hosain et al (2018). LAI of different rice varieties were not significant in all the three stages. LAI of all varieties increased up to 60 DAT there after it was decreased. Similar results were reported by Mishra \& Dash (2014). However, highest LAI was recorded in hybrid

Table 1 Growth parameter of rice varieties (Pooled data of two years)

\begin{tabular}{|c|c|c|c|c|c|c|c|c|c|}
\hline \multirow[t]{2}{*}{ Variety } & \multicolumn{3}{|c|}{ Plant height $(\mathrm{cm})$} & \multicolumn{3}{|c|}{ Tillers $\mathrm{m}^{-2}$} & \multicolumn{3}{|c|}{ DMA $\left(\mathrm{g} \mathrm{m}^{-2}\right)$} \\
\hline & 30 DAT & 60 DAT & $90 \mathrm{DAT}$ & $30 \mathrm{DAT}$ & 60 DAT & 90 DAT & 30 DAT & 60 DAT & 90 DAT \\
\hline $27 \mathrm{P} 22$ & 54.0 & 79.4 & 95.1 & 229.6 & 361.5 & 313.2 & 254.0 & 672.1 & 1116.4 \\
\hline 27P37 & 58.1 & 84.0 & 98.6 & 238.4 & 394.5 & 376.5 & 268.5 & 721.6 & 1209.1 \\
\hline 27P36 & 56.5 & 82.9 & 97.8 & 214.5 & 370.4 & 326.1 & 272.3 & 769.4 & 1250.5 \\
\hline 28P67 & 52.6 & 80.8 & 92.2 & 247.2 & 443.2 & 406.3 & 288.5 & 802.3 & 1306.8 \\
\hline 27P31 & 55.2 & 81.8 & 96.0 & 199.8 & 407.9 & 378.4 & 258.4 & 772.8 & 1253.3 \\
\hline 29P01 & 57.1 & 89.2 & 102.5 & 233.5 & 357.3 & 326.7 & 263.7 & 754.6 & 1245.8 \\
\hline ArizeTejgold & 55.3 & 83.7 & 94.3 & 207.0 & 315.6 & 301.9 & 205.6 & 642.2 & 1082.1 \\
\hline Arize 6129 & 55.1 & 81.9 & 93.4 & 231.3 & 350.1 & 322.6 & 226.2 & 635.5 & 1113.9 \\
\hline IET4786 & 50.5 & 76.1 & 78.2 & 159.8 & 284.0 & 243.3 & 212.8 & 561.4 & 875.9 \\
\hline S. Em. $( \pm)$ & 3.16 & 4.15 & 5.65 & 30.46 & 29.16 & 26.38 & 36.25 & 58.11 & 61.20 \\
\hline $\mathrm{CD}(\mathrm{p}=0.05)$ & NS & NS & 16.94 & NS & 87.44 & 79.10 & NS & 174.27 & 183.56 \\
\hline
\end{tabular}

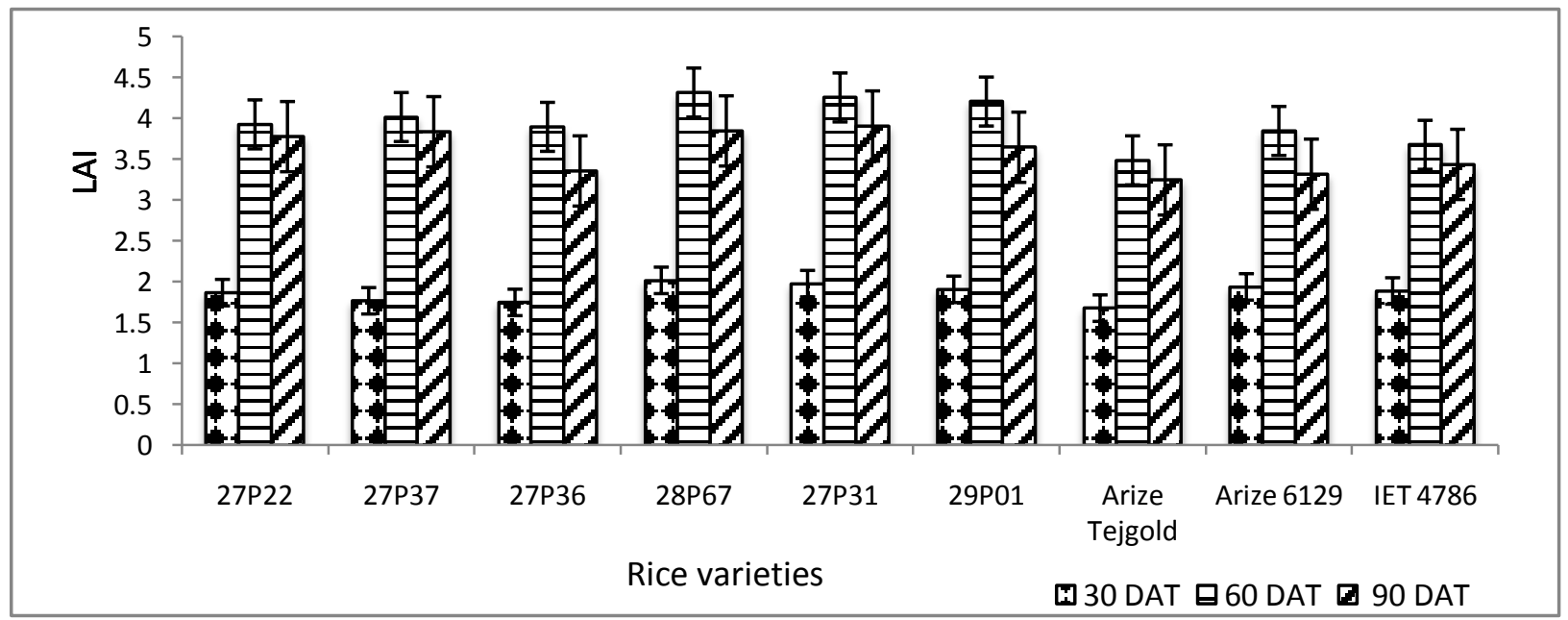

Figure 4: Leaf Area Index (LAI) of different rice varieties 
Table 2 Yield components, yield and Harvest Index of rice varieties (Pooled data of two years)

\begin{tabular}{|c|c|c|c|c|c|c|}
\hline \multirow{2}{*}{ Variety } & \multirow{2}{*}{ Panicle $\mathrm{m}^{-2}$} & \multirow{2}{*}{$\begin{array}{l}\text { Filled grains } \\
\text { panicle }^{-1}\end{array}$} & \multirow{2}{*}{ Test weight (g) } & \multicolumn{2}{|c|}{ Yield $\left(\right.$ tha $\left.^{-1}\right)$} & \multirow{2}{*}{$\begin{array}{c}\text { Harvest Index } \\
(\%)\end{array}$} \\
\hline & & & & Grain & Straw & \\
\hline $27 \mathrm{P} 22$ & 278.5 & 136.4 & 22.4 & 5.84 & 5.94 & 49.56 \\
\hline 27P37 & 319.3 & 141.6 & 23.6 & 6.63 & 6.78 & 49.45 \\
\hline 27P36 & 289.2 & 155.1 & 24.1 & 6.44 & 6.76 & 48.77 \\
\hline $28 \mathrm{P} 67$ & 351.4 & 158.2 & 24.9 & 7.13 & 7.23 & 49.65 \\
\hline 27P31 & 331.5 & 157.8 & 22.7 & 6.83 & 6.95 & 49.55 \\
\hline 29P01 & 282.8 & 154.9 & 23.0 & 6.12 & 6.22 & 49.58 \\
\hline ArizeTejgold & 259.9 & 137.5 & 22.4 & 5.06 & 5.44 & 48.19 \\
\hline Arize 6129 & 265.7 & 143.7 & 23.3 & 5.38 & 5.68 & 48.66 \\
\hline IET4786 & 202.6 & 118.3 & 19.8 & 3.54 & 4.64 & 43.25 \\
\hline $\operatorname{SEm}( \pm)$ & 16.51 & 11.36 & 0.63 & 0.39 & 0.40 & - \\
\hline $\mathrm{CD}(\mathrm{p}=0.05)$ & 49.52 & 34.07 & 1.87 & 1.17 & 1.20 & - \\
\hline
\end{tabular}

Table 3 Time required for Panicle Emergence (PE) 50\% flowering and total duration of different rice varieties.

\begin{tabular}{|c|c|c|c|}
\hline Varieties & $\begin{array}{l}\text { Required time for PE } \\
\text { (Days) }\end{array}$ & $\begin{array}{l}\text { Required time for } 50 \% \text { Flowering } \\
\text { (Days) }\end{array}$ & Total Duration of crop (Days) \\
\hline $27 \mathrm{P} 22$ & 57 & 62 & 129 \\
\hline 27P37 & 59 & 64 & 128 \\
\hline $27 \mathrm{P} 36$ & 60 & 67 & 129 \\
\hline $28 \mathrm{P} 67$ & 58 & 66 & 127 \\
\hline $27 \mathrm{P} 31$ & 58 & 65 & 129 \\
\hline 29P01 & 57 & 64 & 130 \\
\hline ArizeTejgold & 56 & 62 & 125 \\
\hline Arize 6129 & 56 & 61 & 120 \\
\hline IET4786 & 53 & 60 & 120 \\
\hline $\operatorname{SEm}( \pm)$ & 0.822 & 0.684 & 0.979 \\
\hline $\mathrm{CD}(\mathrm{p}=0.05)$ & 2.486 & 2.068 & 2.960 \\
\hline
\end{tabular}

28P67 followed by 27P31 and lowest in Arize Tejgold in all the three growth stages (Table 1).

Dry bio-mass of different rice varieties recorded at 30 DAT was found statistically not significant. However dry bio-mass at 60 DAT and 90 DAT were found statistically significant. At 60 DAT dry matter accumulation ranged from $661.4 \mathrm{~g} / \mathrm{m}^{2}$ to $802.3 \mathrm{~g} / \mathrm{m}^{2}$ while at 90 DAT, the range was $875.9 \mathrm{~g}$ to $1306.8 \mathrm{~g} / \mathrm{m}^{2}$. The significantly higher dry bio-mass was observed in variety $28 \mathrm{P} 67$ followed by 27P31 and significantly lowest in IET-4786 at both 60 DAT and 90 DAT (Table 1).

Number of panicles $\mathrm{m}^{-2}$ was found significant between the hybrid and control HYV. Significantly lowest number of panicles $\mathrm{m}^{-2}$
(202.6) was recorded in HYV (IET-4786) and highest in Hybrid varieties. Among the eight hybrids, maximum number of panicles $\mathrm{m}^{-2}$ was obtained in 28P67 (351.4) which were followed by 27P31 and 27P37. Hybrid vigour is the probable reason for this significant difference in panicle number $\mathrm{m}^{-2}$. The results are also in agreement with Yang et al. (2007).

\subsection{Yield and yield attributes}

The number of filled grains panicle ${ }^{-1}$ was varied significantly among the hybrids as well as in between hybrids and HYV (control). Highest value of 158.2 was recorded in hybrid variety 28P67 and lowest value of 118.3 in HYV IET4786. Akram et al. (2007) also reported that all most all the hybrids produced more 
number of grains panicle ${ }^{-1}$. However, number of filled grains panicle $^{-1}$ for hybrids 27P36, 27P31, and 29P01 were significantly higher over HYV IET4786 though they are at par with hybrid 28P67 (Table.2).

Like the number of filled grains panicle ${ }^{-1}$, test weight of grains was found statistically significant among the hybrids as well as in between hybrids and HYV. Significantly higher test weight was recorded in hybrids and lowest in HYV (IET 4786). Akram et al. (2007) also reported that hybrids produced higher weight of 1000 grain than check variety. However, among the hybrids, Variety 28P67 recorded the highest test weight of $24.9 \mathrm{~g}$ followed by $27 \mathrm{P} 36$ and 27P37 whereas the lowest test weight was in 27P22 (Table.2).

Grain yield was significantly varied among the all varieties. Significantly higher grain yield $\left(7.13 \mathrm{tha}^{-1}\right)$ was reported in 28P67 followed by 27P31 (6.83 $\left.\mathrm{tha}^{-1}\right)$ and 27P37 $\left(6.63 \mathrm{t} \mathrm{ha}^{-1}\right)$ might be due to higher number of panicles $\mathrm{m}^{-2}$, filled grains panicle ${ }^{-1}$, test weight etc. However, the lowest grain yield of $3.54 \mathrm{t} \mathrm{ha}^{-1}$ was obtained in HYV IET 4786 (Table.2). Hybrid rice has a distinct yield advantage over the conventional varieties (Khushik et al. 2011). Sarwar et al. (2010) also reported that the hybrid cultivars produced longer panicle, higher number of filled grain panicle ${ }^{-1}$ heavier grains and finally higher grain yield $\mathrm{ha}^{-1}$ than inbreed rice cultivars. Aktar et al. (2016) also reported that hybrid varieties exhibited superiority in respect of growth characters, yield and yield attributes such as plant height, tillers hill ${ }^{-1}$, leaf area index, total dry matter hill ${ }^{-1}$, weight of 1000 grains, biological yield over the inbred. Similar results were also reported by many researchers like Akram et al. (2007); Uddin et al. (2007), Maiti \& Bhattacharya (2012) and Tanmoy (2012).

From the experiment it was found that straw yield also varied significantly among the tested varieties. Significantly higher straw yield $\left(7.23 \mathrm{t} \mathrm{ha}^{-1}\right)$ was recorded in 28P67 which was at par with 27P31, 27P37, 27P36 and 29P01 and the lowest straw yield (4.64t $\mathrm{ha}^{-1}$ ) was with IET 4786 (Table.2). Similar results were reported by Singh \& Bharadwaj (2007), these researchers suggested that hybrid variety gave more straw yield and other growth parameter than any inbreed variety.

Regarding harvest index (HI), it was found that all the hybrids gave higher HI over control variety HYV. Among the various tested hybrids, higher harvest index (49.65\%) was noted in 28P67 and lower (48.19\%) in ArizeTejgold. However, HYV IET-4786 recorded the lowest $\mathrm{HI}$ of $43.25 \%$ (Table 2). Similarly, Aktar et al. (2016) reported that hybrid varieties produced more harvest index over the inbred and average harvest index of hybrid genotype ranged between 46.5 and 53.0\%. Hosain et al (2018) also found the same result i.e. highest harvest index was recorded by BRRI hybrid Dhan 3 (43.26\%) over check variety BRRI Dhan 45.

\section{Conclusion}

There was a significant difference in crop performance between the hybrid varieties and HYV Satabdi (IET 4786). Hybrid varieties exhibited better growth over the HYV Satabdi (IET 4786). Rice hybrids also showed significantly higher grain yield and yield attributing characters like panicle $\mathrm{m}^{-2}$, filled grains panicle $^{-1,}$ test weight etc. Among the different rice hybrids, better growth and grain yield $\left(7.13 \mathrm{t} \mathrm{ha}^{-1}\right)$ were obtained from 28P67 followed by 27P31 (6.83 $\left.\mathrm{t} \mathrm{ha}^{-1}\right)$ and 27P37 (6.63 $\left.\mathrm{t} \mathrm{ha}^{-1}\right)$ and the rice hybrid Arize Tejgold was poor performer. Similar trend was also found in case of stover yield and harvest index (HI).

\section{Conflict of interest}

All the authors would like to declare that there is no conflict of interest among themselves that could possibly arise.

\section{References}

Akram M, Rehman A, Ahmad M,Cheema AA (2007) Evaluation of rice hybrids for yield and yield components in three different environments. Journal of Animal Plant Science 17: 3-4

Aktar M, Sarkar SC, Islam MR, Haque MM (2016) Source-Sink Relationship and Yield Performance of Hybrid Rice Varieties in Boro Season. International Journal of Agricultural and Environmental Sciences 1: 39-48.

Anonymous (2018) 10 largest rice producing countries in the world retrieved from https://www.worldatlas.com/articles/thecountries-producing-the-most-rice-in-the-world.html access on 26.08.2018

Bhuiyan MSH, Zahan A, Khatun H, Iqbal M, Alam F, Md. RezaulManir MR (2014) Yield performance of newly developed test crossed hybrid rice variety. International Journal of Agronomy and Agricultural Research 5: 48-54.

Department of Agriculture \& Cooperation (2010) Ministry of Agriculture, Government of India. Guidelines for Seed Production of Hybrid Rice. Available on http://vikaspedia.in/agriculture/cropproduction/package-of-practices/hybrid-rice-seed-production access on 26.08.2018

Gomez KA, Gomez AA (1984) Statistical procedures for agricultural research (2 ed.). John wiley and sons, NewYork, pp 30-120.

Hosain T, Hossain E, Nizam R, Fazle Bari ASM, Chakraborty R (2018) Response of Physiological Characteristics and Productivity of Hybrid Rice Varieties under System of Rice Intensification (SRI) over the Traditional Cultivation. International Journal of Plant Biology \& Research 6: 1085 
Khushik AM, Lashari MI, Memon A (2011) Performance of rice varieties in Sindh \& Balochistan. Journal of Agricultural Research 49: $561-570$

Maiti PK, Bhattacharya B (2012) Effect of nitrogen and phosphorus on growth and yield of hybrid rice (Oryza sativa L.) grown in dry (boro) season. Journal of Interacademicia 16: 643656

Mishra P, Dash D (2014) Rejuvenation of bio-fertilizer for sustainable agriculture and economic development. The Journal of sustainable Development 11: 41-61

Prasad R (2012) Text Book of Field Crops Production Commercial Crop. ICAR, New Delhi (2nd Edn.), Pp. 377.

Sarkar SC, Akter M, Islam MR, Haque MM (2016) Performance of Five Selected Hybrid Rice Varieties in Aman Season. Journal of Plant Sciences 4: 72-79.

Sarwar KMG, Karim AM, MasudRsana SMAJ (2010) Influence of stomatal characteristics on yield and yield attributes of rice. Bangladesh Agriculture University 11: 47-52
Singh C, Singh P, Singh R (2012) Modern Techniques of Raising Field crops. Oxford \& IBH publishing Company Pvt. Ltd. New Delhi. (Second edition)

Singh PK, Bharadwaj V (2007) Effect of different nutrient levels on yield and yield attributes of hybrid and inbred rice varieties. Oryza 44 : 137-139.

Tanmoy S (2012) Response of Nutrient management on varieties of high yielding and hybrid rice. M.Sc. (Ag.) Thesis submitted to the BCKV, Mohanpur, West Bengal, Pp.61-62

Uddin MJ, Abdullah MR, Wazuddin M (2007) Evaluation of yield performance of hybrid rice. Journal of Bangladesh Society of Agriculture, Science and Technology 4: 135-140

Viraktamath BC (2011) Hybrid Rice in India - current Status and Future Prospects. Rice Knowledge Management Portal (RKMP), Directorate of Rice Research Pp. 1-50.

Yang W, Peng S, Laza RC, Visperas RM, Dionisio-Sese ML (2007) Grain yield and yield attributes of new plant type and hybrid rice. Crop Science 47: 1393-1400 